\title{
Section V: Undersea Infrastructure, Systems and Devices
}

\author{
Rule 61 \\ With due regard for the rights of other States, coastal States are entitled to \\ install, operate and maintain undersea systems and devices, whether military \\ or civilian in nature, in their territorial sea, continental shelf and EEZ.
}

\section{Commentary}

1. This Rule reflects customary international law which has long recognized the rights of coastal States to install, operate and maintain underwater systems. Such systems are used for a wide variety of civilian and scientific purposes, such as maintenance and operation of offshore installations, submarine pipelines and cables, preservation of the marine environment and protection against natural disasters (e.g., tsunamis).

2. They also serve a wide variety of military or security purposes. Sensors and other devices have for a long time been used for the detection of submarines and for the protection of certain parts of the coastline against potential enemies, criminals or terrorists.

3. There are only few provisions in UNCLOS (e.g., Article 258 on scientific research installations) or in other treaties addressing the installation of undersea systems and devices used for purposes other than the exploration and exploitation of the natural resources of the EEZ or the continental shelf. Of course, within their internal waters, territorial sea or, where applicable, archipelagic waters coastal/ archipelagic States are entitled to install and operate such systems, whether civilian or military in nature. Coastal and archipelagic States may also install and operate undersea systems and devices, such as undersea systems and devices for the purpose of marine scientific research or in the exercise of other rights and duties in relation to the EEZ or continental shelf. Coastal States are entitled to maintain, repair and protect them. 


\section{Rule 62}

Subject to the coastal States' rights (including its rights to exercise jurisdiction and its rights regarding marine scientific research) and with due regard to the rights of other States, all States are entitled to install, operate and maintain undersea systems and devices for data collection and survey activities, whether military or civilian in nature, on the continental shelf or in the EEZ of other States.

\section{Commentary}

1. Generally, States other than the coastal State may install and operate such systems in the EEZ of other States. Coastal State jurisdiction with respect to the establishment and use of structures and installations is generally limited to structures and its installations for economic purposes and to those structures and installations that may interfere with the rights of the coastal State in its EEZ. ${ }^{1}$ Otherwise, beyond the territorial sea of any State, the freedom to construct installations permitted under international law applies (subject to part 6 of UNCLOS concerning the continental shelf ${ }^{2}$ ). Accordingly, as a rule, the coastal State does not have jurisdiction with respect to installation and structures for military or other non-economic purposes if they do not risk interfering with the coastal State's exercise of its EEZ. Coastal States do, however, have the exclusive right to authorize and regulate drilling on their continental shelves for all purposes. ${ }^{3}$ Insofar as they are used for marine scientific research (MSR), the consent of the coastal State may be required consistent with Part XIII of UNCLOS.

2. UNCLOS does not define the term "marine scientific research", and States have not agreed on the need for-or formulation of - a particular definition. One proposed definition based in part on Article 243 of UNCLOS is that MSR refers to "those activities undertaken in ocean space to expand scientific knowledge of the marine environment and its processes." 4

3. A systematic interpretation of the different UNCLOS provisions leads to the conclusion that MSR must be distinguished from "survey activities". 5 Accordingly, MSR does not include hydrographic surveys, ${ }^{6}$ including military surveys, or operational oceanography.

\footnotetext{
${ }^{1}$ UNCLOS, see chapter "Section IV: Unmanned Maritime Systems", fn. 3, Article 60.

${ }^{2}$ UNCLOS, Article 87.

${ }^{3} \mathrm{UNCLOS}$, Article 81

${ }^{4}$ G. Walker (ed.), Definitions for the Law of the Sea, (Leiden/Boston) (2012), page 241.

${ }^{5}$ See UNCLOS, see chapter "Section IV: Unmanned Maritime Systems", fn. 3, Articles 19 (2)(j), $21(1)(\mathrm{g})$ and 40.

${ }^{6}$ For the importance of hydrographic surveys and nautical charting, including electronic charting, see UNGA resolution A/RES/66/231 of 24 December 2011.
} 
4. Military surveys in foreign EEZs have been conducted by numerous States, including Russia, Japan, Australia, South Africa, China and NATO States. They cannot be considered MSR and they are not covered by the jurisdiction enjoyed by the coastal State in accordance with Article 56 (1)(b)(ii) of UNCLOS. Rather, any form of marine data collection that is not covered by the term "MSR" is a right granted either under "other internationally lawful uses of the sea", or under "other pertinent rules of international law". ${ }^{8}$ This rights may not be impeded or interfered with by the coastal State. Hence, it is safe to conclude that survey activities and operational oceanography not qualifying as marine scientific research are lawful.

5. The States having installed and operating such systems or devices in the EEZ, or whose nationals have installed and operate them, are entitled to take appropriate measures to maintain, repair and protect them. The above conclusion also applies to the continental shelf, if drilling on the shelf is not involved.

\section{Rule 63}

All States are entitled to install and operate undersea systems and devices in the high seas with due regard to the rights of other States.

\section{Commentary}

1. On the high seas, the right to install and operate such systems and devices is recognized by both the "freedom to construct artificial islands and installations" and by "other rules of international law", as provided for in Article 87(1) of UNCLOS.

2. This right is not limited to civilian or scientific systems and devices. The peaceful uses clause in Article 88 of UNCLOS, which according to Article 58(2) of UNCLOS also applies in the EEZ, does not prohibit military uses of the seas that do not qualify as a use or threat of force.

3. It must be borne in mind that in the high seas there is no prohibition of MSR. On the contrary, the freedom of the high seas includes the freedom of scientific research subject to Parts VI and XIII of UNCLOS. It must be noted that scientific research is broader than the UNCLOS term of art "marine scientific research".

\section{Rule 64}

During an armed conflict:

(a) Enemy undersea systems and devices may not be attacked, unless they qualify as lawful targets.

\footnotetext{
${ }^{7}$ UNCLOS, Article 58 (1).

${ }^{8}$ UNCLOS, Article 58 (2).
} 


\section{Commentary}

1. The law of naval warfare is silent on the legal status of undersea systems and devices. It is, however, beyond doubt that they are liable to destruction or capture if they directly contribute to the enemy's military action by nature, location, purpose or use and their total or partial destruction or neutralization, in the circumstances ruling at the time, offers a definite military advantage. Hence, military systems will qualify as lawful military objectives. ${ }^{9}$

2. The same holds true for civilian enemy and neutral systems and devices that directly contribute to the enemy's military action.

(b) Subject to Rule 65, enemy undersea systems and devices may be captured outside neutral waters.

\section{Commentary}

1. The law of naval warfare provides no rules as to the admissibility of the capture of enemy civilian undersea systems and devices. There is, however, no cogent reason to treat such systems and devices differently from enemy vesselswhether merchant or otherwise-or enemy cargoes, which may be captured outside neutral waters. ${ }^{10}$

2. If an enemy undersea system or device that qualifies as a lawful target is located in neutral waters, the Neutral State is under an obligation to terminate that violation of its neutrality. If the Neutral State fails to do so, the opposing belligerent may be entitled to respond to the violation of neutrality, including, if necessary, by the use of force. ${ }^{11}$

\section{Rule 65}

If innocently employed in their normal role, the following enemy civilian undersea systems and devices should be exempt from capture:

(a) Undersea systems and devices exclusively used for non-military scientific missions;

\section{Commentary}

1. In principle, civilian enemy undersea systems and devices are liable to capture. Some undersea systems and devices, however, serve important scientific or humanitarian functions. Therefore, the same principles as those underlying the 1907 Hague Convention (XI) ${ }^{12}$ should be applied. Accordingly, undersea sys-

\footnotetext{
${ }^{9}$ The definition of military objectives is included in Rule 77.

${ }^{10}$ San Remo Manual, see chapter "Section I: Outer Space”, fn. 29, para 135.

${ }^{11}$ Ibid, para 22.

${ }^{12} 1907$ Convention (XI) Relative to Certain Restrictions with Regard to the Exercise of the Right of Capture in Naval War, see chapter "Section IV: Unmanned Maritime Systems", fn. 29.
} 
tems and devices used for non-military scientific missions should be excluded from the right of capture. ${ }^{13}$

2. The term "should" is used in this context because there is not yet sufficient State practice that has crystallized into a rule of customary international law.

(b) Undersea systems and devices exclusively used for preventing or responding to pollution incidents in the marine environment; and

\section{Commentary}

1. Systems exclusively employed for the prevention of pollution incidents, ${ }^{14}$ such as those monitoring and repairing submarines pipelines, should not be liable to capture.

(c) Undersea systems and devices exclusively used for the collection of data necessary to warn the civilian population of natural disasters, such as tsunamis.

\section{Commentary}

1. Systems exclusively employed for the advance warning of natural disasters (e.g. tsunamis) should not be liable to capture.

2. Of course, that protection is dependent on their innocent employment. Accordingly, such systems will no longer be protected from capture and destruction if they are used for the transmission of military data.

\section{Rule 66}

Neutral undersea systems and devices that qualify as lawful targets are liable to capture.

\section{Commentary}

1. Neutral undersea systems and devices qualify as lawful targets if they make an effective contribution to the enemy's military action, by location, purpose or use and their total or partial destruction or neutralization, in the circumstances ruling at the time, offers a definite military advantage.

2. Otherwise, neutral undersea systems and devices are protected by their neutral status, and it is prohibited for Belligerent States to capture them.

3. As distinct from neutral vessels and civil aircraft, ${ }^{15}$ undersea systems and devices cannot at present be used for purposes - such as carriage of contraband-that would make them liable to capture under the law of prize.

\footnotetext{
${ }^{13}$ See also San Remo Manual, fn. 31, para 136(e).

${ }^{14}$ San Remo Manual, ibid, para 136(g).

${ }^{15}$ San Remo Manual, paras 67 and 146.
} 
Open Access This chapter is licensed under the terms of the Creative Commons Attribution 4.0 International License (http://creativecommons.org/licenses/by/4.0/), which permits use, sharing, adaptation, distribution and reproduction in any medium or format, as long as you give appropriate credit to the original author(s) and the source, provide a link to the Creative Commons licence and indicate if changes were made.

The images or other third party material in this chapter are included in the chapter's Creative Commons licence, unless indicated otherwise in a credit line to the material. If material is not included in the chapter's Creative Commons licence and your intended use is not permitted by statutory regulation or exceeds the permitted use, you will need to obtain permission directly from the copyright holder. 